\title{
Early-onset neonatal sepsis and risk factors in the preterm infants
}

\author{
Envera Lekić (D), Sonja Babović (ID, Jelena Vukićević (D), Milorada Nešović iD, Ljubinka Dragaš \\ Department of Neonatology, University Clinical Center of Montenegro, Podgorica, Montenegro
}

\begin{abstract}
Objective: The aim of the study was to identify the risk factors and bacterial microorganisms causing early-onset sepsis in preterm newborn infants.

Methods: The open-label study was prospectively conducted from January to December 2015 in the University Clinical Center, Institute for Children's Diseases, Center of Neonatology Podgorica, Montenegro.

Results: Out of 653 infants admitted (427 full-term, 226 preterm) the study included 71 infants diagnosed with sepsis (full-term infants with sepsis - 32 cases [7.5\%] and preterm newborns with sepsis - 39 cases [17.3\%]). Blood culture was positive in 44 newborns with sepsis (20 full-term, 24 preterm). Out of 24 preterm infants, early-onset sepsis was proven in 8 (dominant pathogen $E$. coli), and late-onset sepsis in 16 patients (dominant pathogens Klebsiella pneumoniae and Staphylococcus $\mathrm{CoN}$ ). Premature birth and low birth weight were identified among the most common neonatal sepsis risk factors. Maternal preeclampsia, premature rupture of membrane and perinatal asphyxia were also identified as significant risk factors for early-onset neonatal sepsis in the preterm newborn infants.

Conclusion: Our data suggest that premature birth and low birth weight are the most common sepsis risk factors together with maternal preeclampsia, premature rupture of membrane and perinatal asphyxia.
\end{abstract}

Keywords: Neonatal sepsis, preterm newborn, early-onset sepsis, late onset sepsis, risk factors.

\section{Introduction}

Infections are an important cause of morbidity and mortality in the neonatal period, particularly in preterm and very low birth weight infants. ${ }^{[1,2]}$ Maternal, environmental, and host factors determine which

\section{Özet: Preterm bebeklerde erken başlangıçlı sepsis ve risk faktörleri}

Amaç: Çalışmanın amacı, preterm yenidoğan bebeklerde erken başlangıçlı sepsise yol açan risk faktörlerini ve bakteriyel mikroorganizmaları tespit etmekti.

Yöntem: Açık uçlu çalışma, Ocak-Aralık 2015 tarihleri arasında Podgorica, Karadağ'daki Üniversite Klinik Merkezi, Çocuk Hastalıkları Enstitüsü, Neonatoloji Merkezi'nde prospektif olarak yürütüldü.

Bulgular: Çalışmaya başvuran 653 bebekten (427 miad, 226 preterm), sepsis tanısı almış 71 bebek (32 sepsisli miad yenidoğan [\%7.5] ve 39 sepsisli preterm yenidoğan [\%17.3]) çalışmaya dahil edildi. Sepsisli 44 yenidoğanda kan kültürü sonucu pozitifti $(20 \mathrm{mi}-$ ad, 24 preterm). Yirmi dört preterm bebekten, erken başlangıçlı sepsis 8 olguda (dominant patojen $E$. coli) ve geç başlangıçlı sepsis 16 olguda (dominant patojenler Klebsiella pneumoniae ve Staphylococcus $\mathrm{CoN}$ ) tespit edildi. Prematüre doğum ve düşük doğum ağırlığı, neonatal sepsis için en yaygın risk faktörleri olarak belirlendi. Maternal preeklampsi, erken membran rüptürü ve perinatal asfiksi de, preterm yenidoğan bebeklerde erken başlangıçlı neonatal sepsis için önemli risk faktörleri olarak belirlendi.

Sonuç: Verilerimiz, prematüre doğum ve düşük doğum ağırlı̆̆1nın, maternal preeklampsi, erken membran rüptürü ve perinatal asfiksi ile birlikte sepsis için en yaygın risk faktörleri olduğunu göstermektedir.

Anahtar sözcükler: Neonatal sepsis, preterm yenidoğan, erken başlangıçlı sepsis, geç başlangiçlı sepsis, risk faktörleri.

infant exposed to a potentially pathogenic organism will develop serious or other potentially invasive infections. ${ }^{[3,4]}$ Neonatal sepsis is defined as a clinical syndrome in an infant 28 days of life or younger, manifested by systemic signs of infection and isolation of a bac-

Correspondence: Envera Lekić, MD. Department of Neonatology, University Clinical Center of Montenegro, Podgorica, Montenegro.

e-mail: dr.envera@yahoo.com / Received: September 8, 2019; Accepted: December 21, 2019

Please cite this article as: Lekić E, Babović S, Vukićević J, Nešović M, Dragaš L. Early-onset neonatal sepsis and risk factors in the preterm infants. Perinatal Journal 2019;27(3):143-149. doi:10.2399/prn.19.0273004 
terial pathogen from blood. We classify it as earlyonset sepsis (EOS) and late-onset sepsis (LOS) depending on the time of onset. EOS is defined as the onset of sepsis in the first 3 days and occurs mostly by infections acquired from mother before or during delivery, while the postnatal environment (community or hospital) plays a direct role in the development of LOS. ${ }^{[5-7]}$ Early diagnosis of neonatal sepsis is challenging because clinical characteristics are non-specific and difficult to differentiate from those of non-infectious etiologies (Table 1). The clinical signs at the onset of sepsis are discrete, nonspecific and can be associated with other neonatal diseases, from mild benign disorders to serious conditions such as: respiratory distress syndrome (RDS), metabolic disorders, intracranial hemorrhage, congenital heart diseases, and a traumatic delivery, making the diagnosis based on physical examination alone difficult. ${ }^{[3,4]}$ Most early-onset bacterial infections are non-focal except in the circumstance of respiratory distress at or shortly after birth, in which the chest radiograph reveals pneumonia. Focal infections are frequent with late-onset neonatal sepsis and include otitis media, pneumonia, soft tissue infections, urinary tract infections, septic arthritis, osteomyelitis, and peritonitis. Few infants have overt meningeal signs, and a high index of suspicion and examination of the cerebrospinal fluid are required for early diagnosis. $^{[3,6,8,9]}$

The aim of this study was to identify the risk factors and bacterial microorganisms causing early-onset sepsis in preterm newborn infants.

\section{Methods}

The open-label study was prospectively conducted from January to December 2015 in the University Clinical Center, Institute for Children's Diseases, Center of Neonatology Podgorica, Montenegro. During the study period, all admitted infants with clinical signs and symptoms of sepsis at the time of admission, or who developed sepsis during their hospitalization were assessed with sepsis screening tool and enrolled in the study. Enrolled patients were divided into two groups: full term newborn infants (FTI) with proven sepsis and preterm infants (PTI) with neonatal sepsis. Preterm newborns were divided into five subgroups according to WHO criteria: BW 500-999 g
Table 1. Clinical manifestation of neonatal sepsis.

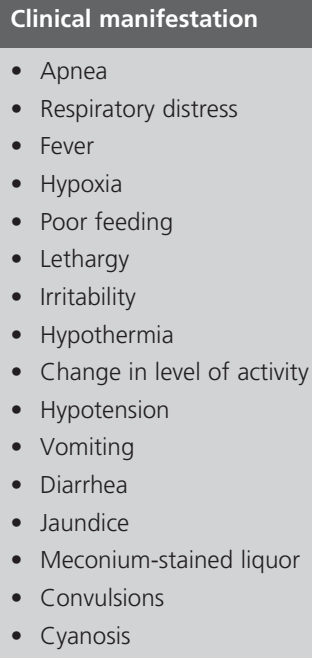

(extremely low birth weight), BW 1000-1499 g (very low birth weight), BW 1500-1999 g, BW 2000-2499 g and $\mathrm{BW}>2500$ g. Study was approved by Ethics Committee of Clinical Center of Montenegro.

The diagnosis of sepsis was made with sepsis screening criteria. Data on the characteristics of newborns, risk factors for the onset of sepsis and their causative agents were collected on a daily basis by qualified medical staff. All data were entered into a survey questionnaire containing the following sections: basic demographic data, data on risk factors (perinatal history, gestational age, birth weight, mode of delivery, premature rupture of membrane (PROM), maternal fever, preeclampsia, invasive diagnostic and therapeutic procedures), information on the causes of neonatal sepsis and clinical manifestation of severe neonatal infections, and the results of hematological, biochemical, bacteriological and other tests (Table 2).

Blood samples were collected from the neonates with suspected sepsis for C-reactive protein (CRP), complete blood count (CBC), and blood cultures. Blood was collected from a peripheral vein. Approximately $1 \mathrm{~mL}$ of blood was inoculated directly into blood culture medium vials and sent to clinical microbiology laboratory for cultivation and subsequent processing. 


\section{Statistical analysis}

Descriptive statistics was used to describe parameters: frequencies, percentages, mean, median, standard deviation (SD), and range (range). A value of $\alpha=0.05$ was adopted for the level of statistical significance. To test for differences between target groups following tests were used: Pearson's $\chi^{2}$ test; Spearman's rank correlation, one-factor ANOVA for proportions, and two-factor ANOVA for proportions. Statistical Package for the Social Science (SPSS) version 23.0 (IBM, Armonk, NY, USA) was used for the statistical analysis.

\section{Results}

A total of 653 neonates were admitted at Center of Neonatology during study period. Out of this number 427 were FTI, and 226 were PTI. During the study period, 71 newborn infants were diagnosed with sepsis (32 FTI [7.5\%]; 39 PTI [17.1\%]). The incidence of sepsis was significantly higher in PTI $(\mathrm{p}<0.001)$ compared to FTI. The mean birth weight of PTI was statistically significant lower compared to FTI $(\mathrm{p}<0.001)$ (Table 3).

In the group of PTI, about 20\% were infants with very low birth weight. Extremely low birth weight was detected in $6.6 \%$ PTI. The sepsis incidence in PTI was highest in extremely low birth weight group $(33.3 \%)$ (Table 4).

Among the enrolled neonates, according to infant age at the onset of symptoms, sepsis was recognized as EOS in 27 cases and as LOS in 44. In PTI EOS was diagnosed in 12, while LOS was diagnosed in 27 patients (Table 5). The sepsis was proven in 44 cases by positive blood culture. In PTI, the onset of sepsis was usually after 4 days or more, while in FTI usually within 3 days (statistically significant difference in the time of onset $\mathrm{p}=0.379)$ (Table 5).

In PTI predominantly isolated pathogen in EOS was E. coli, while in LOS most frequently isolated were Klebsiella pneumoniae and Staphylococcus CoN (Table 6).

In $6.3 \%$ of mothers of FTI and as many as $46.2 \%$ of mothers of PTI, the time from rupture of the membranes to delivery was longer than 18 hours, which is a pathological finding. There was a statistically significant difference in the frequency of water rupture time between the studied groups $(\mathrm{p}<0.001)$.
Table 2. Collected variables

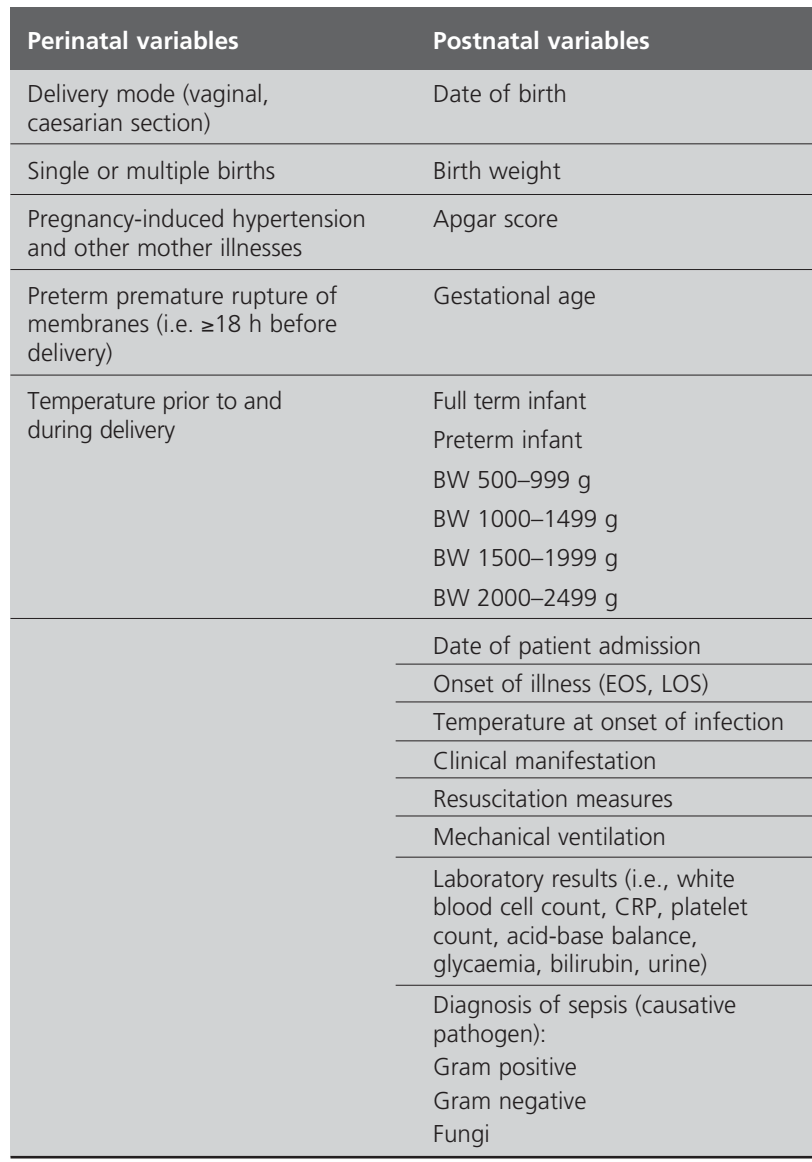

BW: birthweight; EOS: early onset sepsis; LOS: late onsetı sepsis.

Table 3. Birth weight of infants with diagnosed sepsis

\begin{tabular}{lcccccc} 
Birth weight $(\mathbf{g})$ & $\mathbf{n}$ & $\bar{\chi}$ & SD & Med & Min & Max \\
Preterm infants & 39 & 1934.6 & 634.5 & 1870.0 & 720.0 & 3770.0 \\
Full term infants & 32 & 3486.9 & 621.5 & 3475.0 & 2050.0 & 4770.0 \\
Total & 71 & 2634.2 & 997.3 & 2590.0 & 720.0 & 4770.0 \\
\hline
\end{tabular}

Table 4. Birth weight of preterm infants (PTI) with diagnosed sepsis.

\begin{tabular}{lcccc} 
Birth weight (g) & $\begin{array}{c}\text { No of } \\
\text { PTI }\end{array}$ & $\%$ & $\begin{array}{c}\text { No of PTI } \\
\text { with sepsis }\end{array}$ & $\begin{array}{c}\text { Incidence of sepsis } \\
\text { (100 newborn) }\end{array}$ \\
\hline 500-999 & 15 & 6.6 & 5 & 33.3 \\
$1000-1499$ & 29 & 1.8 & 6 & 20.7 \\
$1500-1999$ & 72 & 31.8 & 14 & 19.4 \\
$2000-2499$ & 64 & 27.8 & 8 & 12.5 \\
$>2500$ & 48 & 20.7 & 6 & 12.5 \\
Total & 228 & 100 & 39 & 17.1 \\
\hline
\end{tabular}


Table 5. Infants with diagnosed sepsis.

\begin{tabular}{|c|c|c|c|c|c|c|c|}
\hline \multirow[b]{2}{*}{ Blood culture results } & \multicolumn{3}{|c|}{ Preterm infants } & \multicolumn{3}{|c|}{ Full term infants } & \multirow[b]{2}{*}{ Total $(\%)$} \\
\hline & EOS $<72 h$ & $\operatorname{LOS}>72 h$ & n (\%) & EOS $<72 h$ & $\operatorname{LOS}>72 h$ & n (\%) & \\
\hline Proven sepsis & 8 & 16 & $24(62)$ & 9 & 11 & $20(63)$ & 44 \\
\hline Possible sepsis & 4 & 11 & $15(38)$ & 6 & 6 & $12(37)$ & 27 \\
\hline Total, n (\%) & $12(31)$ & $27(69)$ & $39(100)$ & $15(47)$ & $17(53)$ & $32(100)$ & $71(100)$ \\
\hline
\end{tabular}

EOS: early onset sepsis; LOS: late onsetı sepsis.

Pre-pregnancy and during pregnancy maternal disease was not significantly different $(\mathrm{p}=0.133)$. A statistically significant difference was found with respect to the presence of pre-eclampsia, with a significantly higher prevalence in mothers of PTI diagnosed with sepsis $(\mathrm{p}=0.035)$.

Differences in the clinical manifestations of sepsis in PTI and FTI were analyzed. PTI were more likely to have symptoms and signs of a respiratory system $(\mathrm{p}=0.009)$, primarily in the form of cyanosis $(\mathrm{p}=0.003)$ and tendencies of apnea $(\mathrm{p}<0.001)$, whereas changes in skin and navel $(\mathrm{p}=0.037$, ie $\mathrm{p}=0.015)$ were significantly more frequent in FTI, as well as signs of CNS involvement $(\mathrm{p}=0.018)$.

Laboratory indicators of sepsis in both groups of infants were analyzed in detail and no statistically significant differences were observed in most parameters. The most common pathological findings in the PTI were leukopenia (56.4\%), hypoxemia (51.3\%) and thrombocytopenia in $46.2 \%$ of infants. Hypoxemia $(37.5 \%)$ and thrombocytopenia (34.4\%) were domi- nant in the FTI. There was a significantly higher prevalence of hypoxemia in the PTI $(\mathrm{p}=0.003)$. PTI most often had an Apgar score of 4-7 (43.6\%), whereas term infants most often had an $8-10(65.6 \%)$. There was a significant difference in the degree of Apgar score between the study groups $(\mathrm{p}=0.035)$. PTI and FTI most often had high and very high CRP at admission $(79.5 \%$ vs. $68.8 \%$, respectively). There was no statistically significant difference in the degree of CRP between the study groups $(\mathrm{p}=0.439)$.

Both PTI and FTI were mostly cured. There was no statistically significant difference in the frequency of outcomes between the study groups $(\mathrm{p}=0.243)$ (Table 7).

When analyzing duration of hospitalization (Table 8), it was observed that PTI spent on average 33.5 days in the hospital (range: $0.0-111.0$ ), while in FTI the hospitalization was on average significantly shorter with 12.5 days (range: $0.0-33.0$ ). There was a statistically significant difference in the median number of hospitalization days between the study groups $(\mathrm{p}<0.001)$.

Table 6. Isolated pathogens according to onset of sepsis and birth weight.

\begin{tabular}{|c|c|c|c|c|c|}
\hline \multirow[b]{2}{*}{ Birth weight (g) } & \multicolumn{4}{|c|}{ Onset of disease } & \multirow[b]{2}{*}{ Total } \\
\hline & $\leq 3$ days & & 4-28 days & & \\
\hline 500-999 & E. coli & 2 & K. pneumoniae & 1 & 3 \\
\hline \multirow[t]{3}{*}{ 1000-1499 } & - & - & K. pneumoniae & 1 & \multirow[t]{3}{*}{4} \\
\hline & - & - & Staphylococcus CoN & 2 & \\
\hline & - & - & Pseudomonas & 1 & \\
\hline \multirow[t]{4}{*}{ 1500-1999 } & E. coli & 2 & Serratia & 1 & \multirow[t]{4}{*}{8} \\
\hline & & & Enterobacter & 1 & \\
\hline & & & Staphylococcus CoN & 3 & \\
\hline & & & Pseudomonas & 1 & \\
\hline \multirow[t]{2}{*}{ 2000-2499 } & E. coli & 1 & K. pneumoniae & 2 & \multirow[t]{2}{*}{5} \\
\hline & Serratia & 1 & E. coli & 1 & \\
\hline \multirow[t]{2}{*}{$\geq 2500$} & Streptococcus alpha haem. GA & 1 & K. pneumoniae & 2 & 4 \\
\hline & K. pneumoniae & 1 & & & \\
\hline
\end{tabular}




\section{Discussion}

Despite the use of new generations of antibiotics and supportive treatment, infections in infants due to high morbidity and mortality remain a significant problem especially in children of very low body weight. ${ }^{[1,2,10]}$ In highly developed countries (such as USA and Australia), the incidence of neonatal bacterial sepsis ranges from 1.5-3.5/1000 live births for EOS to 6-9/1000 live births for LOS. It varies between different countries and regions: 7.1-38/1000 live births in Asia, 6.5-23/1000 in Africa and 3.5-8.9/1000 in South America and the Caribbean. ${ }^{[1,2,10,11]}$ During year 2015, 653 infants were admitted to Clinical Center of Montenegro - 427 FTI (65.4\%) and 226 PTI (34.7\%). Out of 653 infants, sepsis was diagnosed in 71 cases (32 FTI [7.5\%]; 39 PTI [17.1\%]) with the incidence of sepsis being significantly higher in PTI $\left(\chi^{2}=13.544 ; \mathrm{p}<0.001\right)$. These results are in accordance with previously published studies with sepsis incidence 3-10 times higher in PTI. ${ }^{[10-12]}$ Immaturity of the immune system, use of medical devices, invasive diagnostic and therapeutic procedures, long hospitalization are some of the possible causes for higher sepsis incidence in PTI. ${ }^{[3,4,13,14]}$

The increased risk of infection correlates with body weight. Infants with low body weight are prone to develop the infection. ${ }^{[3,15]}$ Newborns weighing less than 1500 grams are 8 times more likely to have sepsis than babies born at term. ${ }^{[10,12]}$ In our study, we observed higher incidence of sepsis in low body weight PTI as well. Similar results were published in a multicenter study by The Eunice Kennedy Shriver National Institute of Child Health and Human involving 15 US university centers analyzing the rates of EOS and LOS among nearly 400,000 live births. The overall rate of early neonatal sepsis was $0.98 / 1000$ live births with a frequency inversely proportional to birth weight (401-1500 g, $10.96 / 1000$; $1501-2500$ g, $1.38 / 1000 ;>2500 \mathrm{~g}$, $0.57 / 1000)$. The incidence of LOS sepsis is also increased in low birth weight infants according to Neonatal Research Network with $43 \%$ in infants weighing $401-750 \mathrm{~g}, 28 \%$ in infants weighing $751-1000 \mathrm{~g}$, $15 \%$ in infants weighing $1001-1250 \mathrm{~g}$ and $7 \%$ for infants weighing $1251-1500 \mathrm{~g} .{ }^{[11,16]}$

The "gold" standard when diagnosing neonatal sepsis is isolation of a microorganism from blood sample. According to available data, the rate of positive blood
Table 7. Disease outcome.

\begin{tabular}{|c|c|c|c|c|c|c|}
\hline \multirow[b]{2}{*}{ Outcome } & \multicolumn{2}{|c|}{ Preterm infants } & \multicolumn{2}{|c|}{ Full term infants } & \multicolumn{2}{|c|}{ Total } \\
\hline & $\mathbf{n}$ & $\%$ & $\mathbf{n}$ & $\%$ & $\mathbf{n}$ & $\%$ \\
\hline Cured & 35 & 89.7 & 32 & 100 & 67 & 94.3 \\
\hline Lethal outcome & 4 & 10.3 & 0 & 0 & 4 & 5.7 \\
\hline Total & 39 & 100.0 & 32 & 100.0 & 71 & 100.0 \\
\hline
\end{tabular}

Table 8. Duration of hospitalization in infants with diagnosed sepsis.

\begin{tabular}{lcccccc}
$\begin{array}{l}\text { Duration of } \\
\text { hospitalization } \\
\text { (days) }\end{array}$ & $\mathbf{n}$ & $\bar{\chi}$ & SD & Med & Min & Max \\
Preterm infants & 39 & 36.6 & 24.7 & 33.5 & 0.0 & 111.0 \\
Full term infants & 32 & 14.8 & 9.1 & 12.5 & 0.0 & 33.0 \\
\hline
\end{tabular}

culture is highly variable and is reported to be between $25-60 \%$ and rarely high up to $82 \% .^{[5,7,1]}$ In our study sepsis was verified in 44 infants (62\%). Possible reason for negative blood culture in remaining 27 infants might be initial antibacterial therapy started at the home medical institution, prior to admission. Among other reasons we must mention small volume of a blood sample for blood culture in critically ill infants with very low birth weight, blood sampling before the onset of sepsis, potential contamination of the blood sample and the possibility that cause of sepsis could not be detected with the available diagnostic methods. ${ }^{[5]}$

In 24 preterm infants enrolled in our study EOS was verified in 8 , and LOS in remaining 16 patients. Most frequently isolated pathogens were $K$. pneumoniae (15.4\%) and E. coli (15.3\%) among Gram negative bacteria and Staph. CoN (12.8\%) in Gram positive bacteria. When analyzing differences in EOS and LOS etiology there is a strong correlation between EOS and E. coli, as well as between LOS and Staph. CoN and K. pneumoniae.

Epidemiological studies have shown a tendency of increase in the incidence of sepsis caused by Gram negative bacteria throughout Europe. The importance of this finding is related to increasing antimicrobial resistance of Gram negative bacteria. Enterobacteriaceae: Enterobacter spp., Klebsiella spp., and Serratia spp. are characterized with polysaccharide capsules that contribute to their virulence by preventing opsonization, phagocytosis and bacterial lysis. In preterm infants with already qualitatively and quantitatively immature immune system, 
these bacteria can cause severe neonatal sepsis with severe complications and poor outcome..$^{[3,17]}$

Published data suggest that duration of hospitalization is longer in PTI diagnosed with sepsis, and lethal outcome is more frequent compared to FTI with sepsis especially if causative agent is Gram negative bacteria. ${ }^{[3,10,12,14]}$ In our study it was observed that PTI spent on average 33.5 days in the hospital (range: 0.0-111.0), while duration of stay in FTI was on average significantly shorter, 12.5 days (range: $0.0-33.0$ ).

Blood count analysis showed no significant differences between PTI and FTI in our study. CRP, one of the most intensively studied, the most widely available and the most used laboratory test for the diagnosis of neonatal sepsis is considered to be "specific" but "late" marker of neonatal infection, as evidenced in our study as well. ${ }^{[1,17-19]}$ In both PTI and FTI a high level $(\geq 20$ $\mathrm{mg} / \mathrm{l}, 100 \%, 98.6 \%$, respectively) and very high CRP ( $\geq 100 \mathrm{mg} / \mathrm{l}, 79.5 \%$ and $68.8 \%$, respectively) was measured. Clinical manifestation, which can be difficult to differentiate from those of non-infectious etiologies, was presented differently in PTI and FTI. In PTI apnea and/or cyanosis, impaired spontaneous activity, hypotonia and significantly frequent hypothermia were verified while CNS symptoms as well as skin and navel related symptoms were more frequent in FTI.

Since blood analysis can result negative when trying to isolate bacteria with blood count and CRP showing indefinite values and indefinite clinical presentation, we also have to analyze risk factors when trying to set a diagnosis of sepsis. According to the results of our study several mother and infant related risks for neonatal sepsis were defined. Most significant mother related risk factor was premature membrane rupture (longer than $18 \mathrm{~h}$ before delivery). It occurred in $46.2 \%$ mother of PTI, which was significantly different compared to mother of FTI. Additionally, preeclampsia in mothers was found to be significant contributor to higher incidence of sepsis in PTI. Among infant related risk factors perinatal asphyxia was detected to be significant risk factor especially in PTI (Apgar score $\leq 7$; 0-3 20.5\%, 4-7 $43.6 \%)$.

\section{Conclusion}

Taking into account published data and results of our study, it becomes obvious that neonatal sepsis still is an important cause of morbidity and mortality in the neonatal period, particularly in preterm and very low birth weight infants. With early diagnosis being challenging due to non-specific clinical characteristics we must rely on isolation of bacteria and estimation of mother and neonatal risk factors. According to results of our study premature birth and low birth weight are identified among the most significant neonatal sepsis risk factors. Maternal preeclampsia, premature rupture of membrane and perinatal asphyxia were identified as significant mother related risk factors for early-onset neonatal sepsis in the preterm newborn infants.

Conflicts of Interest: No conflicts declared.

\section{References}

1. World Health Organization. WHO Global Health Observatory (GHO) data. Causes of child mortality 2015. [Accessed 2016 July 04] [Internet]. Geneva: WHO Press; 2015. Available from: http://www.who.int/gho/child_health/ mortality/causes/en/

2. World Health Organization. WHO Global Health Observatory (GHO) data. Neonatal mortality 2015. [Accessed 2016 July 01] [Internet]. Geneva: WHO Press; 2105. Available from: http:// www.who.int/gho/child_health/mortality/neonatal/en/

3. Nizet V, Kelin JO, Bacterial sepsis and meningitis. In: Wilson CB, Nizet V, Maldonado YA, Remington JS, Kelin JO, editors. Remington and Klein's infectious diseases of the fetus and newborn infant. 8th ed. Philadelphia, PA: Elsevier Saunders; 2015. p. 217-90.

4. Edwards MS. Postnatal bacterial infections. In: Fanaroff A, Martin RJ, Walsh MC, editors. Neonatal - perinatal medicine. Diseases of the fetus and infant. 8th ed. St. Louis, MO; Mosby Elsevier; 2006. p. 793-829.

5. Cant AJ, Gennery AJ, Russell AB, Isaacs D. Neonatal infection. In: Rennie J, editor. Rennie \& Roberton's textbook of neonatology. 5th ed. St. Louis, MO; Elsevier; 2012. p. 101342.

6. Ferrari P, Walen LD. Neonatal bacterial sepsis. Gleason CA, Devaskar SU, editors. Avery's diseases of the newborn. 9th ed. Philadelphia, PA: Elsevier Saunders; 2012. p. 538-50.

7. Paolucci M, Landini MP, Sambri V. How can the microbiologist help in diagnosing neonatal sepsis? Int J Pediatr 2012; 2012:120139.

8. Pomerantz WJ, Weiss SL, Torrey SB, Kaplan SL, Randolph AG, Wiley JF. Systemic inflammatory response syndrome (SIRS) and sepsis in children: definitions, epidemiology, clinical manifestations, and diagnosis. Up To Date 2015; Waltham, MA. [Accessed on February 16th, 2015]

9. Argent AC. Recognizing pediatric sepsis: do the concepts help us to focus appropriately? Pediatr Crit Care Med 2016;17: $460-1$. 
10. Stool BJ, Shane AL. Infections of the neonatal infant. In: Kliegman S, Stanton BF, St. Geme JF III, Schor NF, editors. Nelson textbook of pediatrics. Vol. I. 20th ed. Philadelphia, PA: Elsevier Saunders; 2015. p. 909-25.

11. Isaacs D. Epidemiology. In: Isaacs D, editor. Evidence-based neonatal infections. Hoboken, NJ: Wiley; 2014. p. 5-10.

12. Embree JE, Alfattoh NI. Infections in the newborn. In: MacDonald MG, Seshia MM, editors. Avery's neonatologypatophysiology and management of the newborn infant. 7th ed. Philadelphia, PA: Lippincott Company; 2015. p. 930-81.

13. Williams CB, Eisenstein EM, Cole SF. Immunology the fetus and newborn. In: Gleason CA, Devaskar SU, editors. Avery's diseases of the newborn. 9th ed. Philadelphia, PA: Elsevier Saunders; 2012. p. 445-67.

14. Shane AL, Sánchez PJ, Stoll BJ. Neonatal sepsis. Lancet 2017;390(10104):1770-80.

15. Ramos GA, Moore TR, Kelly TF, Hull AD, Wallen LD, Gleason CA. Maternal health affecting neonatal outcome. In:
Gleason CA, Devaskar SU, editors. Avery's diseases of the newborn. 9th ed. Philadelphia, PA: Elsevier Saunders; 2012. p. $75-128$

16. Liu L, Oza S, Lawn JE, Hogan DR, Mathers C, Cousens SN. Neonatal cause-of-death estimates for the early and late neonatal periods for 194 countries: 2000-2013. Bull World Health Organ 2015;93:19-28.

17. Heljić S, Karamehić J, Dizdarević Z. Neonatalna imunologija. In: Karamehić J, Dizdarević Z, editors. Klinička imunologija. 1st ed. Sarajevo: Svjetlost; 2007. p. 225-38.

18. Martić J, Janković B, Rakonjac Z, Pejić K, Vasiljević Z. Klinička i laboratorijska dijagnostika teških bakterijskih infekcija novorodenčeta. In: Problemi u pedijatriji 2013. Beograd: Zavod za udžbenike i nastavna sredstva; 2014. p. 1-21.

19. Janković B, Veljković D, Rakonjac Z, Jevtić D, Martić J. Nove mogućnosti i praktični aspekti dijagnostike neonatalne sepse. In: Problemi u pedijatriji 2005. Beograd: Zavod za udžbenike i nastavna sredstva; 2006. p. 178-91.

Bu makalenin kullanım izni Creative Commons Attribution-NoCommercial-NoDerivs 3.0 Unported (CC BY-NC-ND3.0) lisansı aracilığılyla bedelsiz sunulmaktadır. / This work is licensed under the Creative Commons Attribution-NonCommercial-NoDerivs 3.0 Unported (CC BY-NC-ND3.0) License. To view a copy of this license, visit http://creativecommons.org/licenses/by-nc-nd/3.0/ or send a letter to Creative Commons, PO Box 1866 , Mountain View, CA 94042, USA. 